\title{
超音波造影剂を用いた移植腎血流測定の試み
}

\author{
${ }^{11}$ 近畿大学医学部堺病院泌尿器科（主任：秋山隆弘教授） \\ 2)近畿大学医学部泌尿器科学教室（主任：栗田 孝教授） \\ ${ }^{3)}$ 長寿クリニック超音波検查室

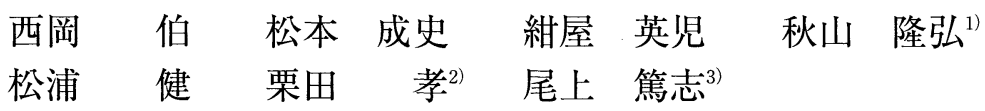

\section{RENAL TRANSPLANT BLOOD FLOW MEASUREMENT USING ULTRASONIC CONTRAST AGENTS} \\ Tsukasa Nishioka, Seiji Matsumoto, Eiji Konya, Takahiro Akiyama", \\ Tskeshi Matsuura, Takashi Kurita ${ }^{2)}$ and Atsushi Onoue ${ }^{3)}$ \\ ${ }^{1)}$ Department of Urology, Sakai Hospotal, Kinki University School of Medicin (Director : Prof. T. Akiyama) \\ ${ }^{2)}$ Department of Urology, Kinki University School of Medicin（Director : prof. T. Kurita) \\ ${ }^{3)}$ Cyozyu Clinic
}

We studied the renal transplant blood flow using an ultrasonic contrast agent. The contrast medium was injected intravenously and produced blood flow enhancement for at least 60 seconds. Measuremements were made from the recorded Doppler spectra. Fourteen renal transplant recipients were inverstigated by color Doppler echography. Blood flow in the interlobular artery could be analyzed in all patients using a contrast, agent, as compared with 2 patients $(14 \%)$ by a conventional method. The average maximum and minimum flow velocity of the interlobular arteries were $0.15 \mathrm{~m} /$ $\mathrm{sec}$ and $0.04 \mathrm{~m} / \mathrm{sec}$. In conclusion, an ultrasonic contrast agent is useful to accurately evaluate peripheral blood supply in renal transplants.

Key words : ultrasonic contrast agents, renal transplant, color Doppler echography

\begin{abstract}
要旨：超音波造影を用いて移植腎の皮質微小循環の評価を試みた。造影検査は超音波造影剂を経静脈的 投与した後，造影効果が発現している間に血流シグナルを同定し解析可能な波型を記録した. 14 例の腎 移植患者を対象に検査を行ったところ従来の超音波カラードップラー法では小葉間動脈レベルの血流ま で評価できたのは 2 例（14\%）にすぎなかったが，造影法では全例で同領域の血流が鮮明に描出され， 波型解析も可能であった. 小葉間動脈の波型解析によって得られた最大血流速と最小血流速の平均值は $0.15 \mathrm{~m} / \mathrm{sec}$ と $0.04 \mathrm{~m} / \mathrm{sec}$ であった．超音波造影剤の応用によって移植腎のより末梢の血流動態が検出し えることが判明した．このことによって従来よりもさらに精度の高い移植腎の病態評価が期待される. キーワード : 超音波造影剤, 移植腎, カラードップラー法
\end{abstract}

\section{緒言}

超音波カラードップラー断層法（以下カラードップ ラー法）は，その簡便性や低侵襲性及び迅速性などか ら, 腎移植後の優れたモニタリング法として広く利用 されるようになった ${ }^{1)}$.しかし従来の方法では, 末梢血 流の評価は葉間動脈のレベルまでの情報であり, 皮質 の微小循環を確実に評価するのは困難であった。そこ で最近臨床応用が可能となった超音波造影剂を用い で3)，outer cortex を支配する小葉間動脈レベルの血 流描出とその評価を試みたので報告する.

\section{手技}

\section{1. 装置と方法}

装置は TOSHIBA SSA350-A Color Doppler Duplex Scanner で 7.5MHz Linear Probe (PLF-703NT) を用い て測定を行った．装置の設定はB モードゲイン：80, カラーゲイン : 8 12, カラーPRF 值 : 7.0 8.0, カ 
ラーフィルター值：203〜236, MI 值：0.8 とした. 検 查はまず B モードエコーグラム上で移植腎を観察し た上で，カラードップラー信号の描出を行い，中心エ コー辺縁の血流 (葉間動脈 interlobar artery：以下 IL) について, パルスドップラー解析した.

次に腎被膜より $1.5 \mathrm{~cm}$ までの深さの部位から検出 される血流（小葉間動脈 interlobular artery：以下 ILB)の描出が可能であれば同様に血流解析を行った. それに引き続き行った造影検査は, 静脈ルートを確保 した上で, $300 \mathrm{mg} / \mathrm{ml}$ に調整した超音波造影剤(レボビ スト ${ }^{\circledR}$ 日本シェーリング) $7 \mathrm{ml}$ の約半量を数秒かけて静 注した。直後から造影効果が発現し，約 1 分間持続す るので，その間にILBの血流シグナルを同定し解析可 能な波型を 2 回記録した. 造影効果が消失した時点で さらに残りの半量を静注し, 同様にILBの波形を検出 し，少なくとも計 3 回の波型解析をもとにその平均值 で，パラメーターである最大血流速 $(\mathrm{V} \max )$, 最小血 流速 (Vmin), Resistive Index (RI = 最大血流速 - 最小 血流速/最大血流速 $)$, Pulsatility Index (PI = 最大血流 速一最小血流速/平均血流速)を算出した，尚，造影法 による検討は，造影効果の持続時間に限りがあるため ILに対する波形解析は行っていない.

\section{2. 血流測定 (表 1)}

近畿大学医学部附属病院泌尿器科で腎移植を施行し た 14 例を対象として血流測定を行った.症例の年齢は 29 歳から 70 歳までで平均 43.9 歳で, 移植後経過年数 は 2 力月から 13 年 8 力月まで平均 6 年 2 力月であっ
た。 また検査時の血清クレアチニン值は 0.8 から 4.7 $\mathrm{mg} / \mathrm{dl}$ で平均 $2.2 \mathrm{mg} / \mathrm{dl}$ であり, 4 例は主に慢性拒絶反 応による腎機能低下があり $3.0 \mathrm{mg} / \mathrm{dl}$ 以上であった. 従 来のカラードップラー法を用いれば，IL の血流は全例 で鮮明に描出され，波型解析も可能であった．各パラ メーターの解析結果の平均值及び標準偏差は, $V \max$ $0.27 \pm 0.09 \mathrm{~m} / \mathrm{sec}, V \min 0.07 \pm 0.04 \mathrm{~m} / \mathrm{sec}$, RI $0.73 \pm$ 0.08, PI $1.55 \pm 0.39$ であった. さらに従来法で ILB の 描出を試みたところ，14 例中 2 例 $(14 \%)$ にのみ解析 可能な波型を検出することができた，検出可能であっ た 2 例はともにクレアチニン值が $2.0 \mathrm{mg} / \mathrm{dl}$ 以下の良 好な移植腎機能を呈していた。これに対し造影カラー ドップラー法を用いたところ，IL の描出はいうまでも なく, ILBの血流も全例で鮮明に描出され波型解析が 可能であったＩLBの波型解析によって得られた各パ ラメーターの平均值及び標準偏差は $V \max 0.15 \pm 0.04$ $\mathrm{m} / \mathrm{sec}, \quad V \min 0.04 \pm 0.01 \mathrm{~m} / \mathrm{sec}$, RI $0.69 \pm 0.09$, PI $1.50 \pm 0.31$ であった。しかし今回の検討した 14 例で は，血清クレアチニン值と IL およびILB の各血流パ ラメーターとの間に有意な相関は認めなかった.

\section{3. 副作用}

造影検査を行った 14 例について, 検査中造影剤の副 作用と考えられる症状を訴えた例はなく，また検査後 6 力月から 10 力月の経過観察中に移植腎機能の著明 な悪化をきたしたものもなかった.

\section{4. 症例の供覧}

従来法及び造影法の両者でIL，ILB の血流解析が

表 1 自験例における血流測定の波型解析から得られた各パラメーター（Vmax, Vmin : m/sec）

\begin{tabular}{|c|c|c|c|c|c|c|c|c|c|}
\hline \multirow{2}{*}{$\begin{array}{c}\text { Case } \\
\text { Age-sex }\end{array}$} & \multirow{2}{*}{$\begin{array}{c}\text { Creatinine } \\
(\mathrm{mg} / \mathrm{dl})\end{array}$} & \multicolumn{4}{|c|}{ IL (fundamental) } & \multicolumn{4}{|c|}{ ILB (contrast) } \\
\hline & & $V \max$ & Vmin & $\mathrm{RI}$ & $\mathrm{PI}$ & $V \max$ & Vmin & $\mathrm{RI}$ & PI \\
\hline $1-46-\mathrm{F}$ & 0.8 & 0.15 & 0.03 & 0.77 & 1.83 & 0.11 & 0.03 & 0.73 & 1.44 \\
\hline 2-51-M & 1.0 & 0.29 & 0.09 & 0.69 & 1.34 & 0.13 & 0.05 & 0.62 & 1.24 \\
\hline 3-38-M & 1.0 & 0.41 & 0.14 & 0.66 & 1.23 & 0.14 & 0.06 & 0.57 & 1.05 \\
\hline 4-70-M & 1.0 & 0.32 & 0.04 & 0.88 & 2.29 & 0.13 & 0.03 & 0.77 & 2.02 \\
\hline $5-50-\mathrm{M}$ & 1.0 & 0.25 & 0.07 & 0.72 & 1.27 & 0.11 & 0.04 & 0.64 & 1.20 \\
\hline $6-52-\mathrm{M}$ & 1.1 & 0.29 & 0.09 & 0.69 & 1.34 & 0.15 & 0.04 & 0.73 & 1.66 \\
\hline 7-30-M & 1.8 & 0.24 & 0.07 & 0.71 & 1.41 & 0.17 & 0.05 & 0.71 & 1.48 \\
\hline 8-32-M & 1.9 & 0.38 & 0.13 & 0.66 & 1.25 & 0.25 & 0.06 & 0.76 & 1.73 \\
\hline $9-29-\mathrm{M}$ & 2.1 & 0.32 & 0.07 & 0.78 & 1.62 & 0.19 & 0.06 & 0.68 & 1.49 \\
\hline 10-39-M & 2.2 & 0.21 & 0.09 & 0.57 & 0.94 & 0.13 & 0.06 & 0.54 & 0.95 \\
\hline $11-29-\mathrm{F}$ & 3.4 & 0.25 & 0.05 & 0.80 & 1.82 & 0.15 & 0.03 & 0.80 & 1.90 \\
\hline $12-29-\mathrm{M}$ & 4.4 & 0.41 & 0.10 & 0.76 & 1.63 & 0.19 & 0.05 & 0.55 & 1.61 \\
\hline $13-52-\mathrm{F}$ & 4.5 & 0.23 & 0.03 & 0.85 & 2.30 & 0.11 & 0.02 & 0.80 & 1.80 \\
\hline $14-38-\mathrm{M}$ & 4.7 & 0.14 & 0.04 & 0.71 & 1.48 & 0.12 & 0.03 & 0.75 & 1.48 \\
\hline
\end{tabular}


図 1 IL の B \& M モード・ドップラー・エコー画像. 左側は従来法, 右側は造影法の 画像及びパラメーターの計測值を示す.

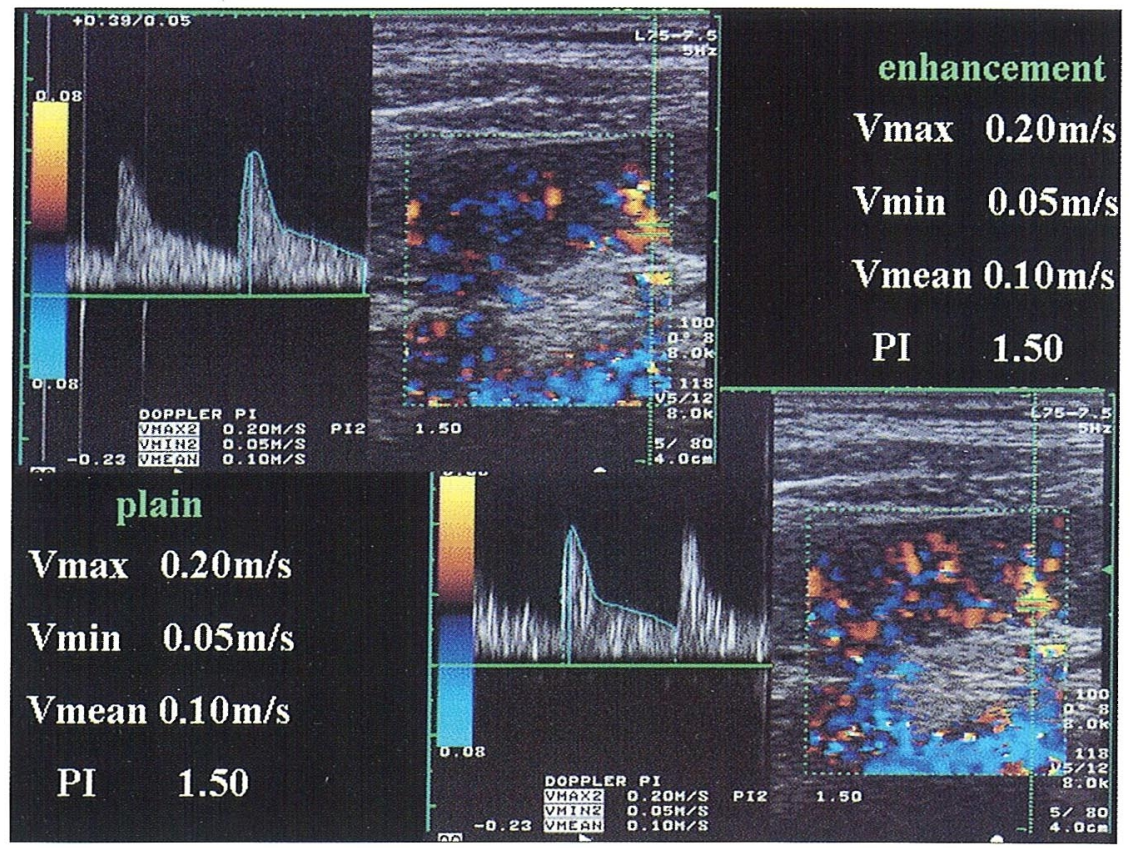

図 2 ILB の B \& M モード・ドップラー・エコー画像. 左側は従来法，右側は造影法 の画像及びパラメーターの計测值を示す.

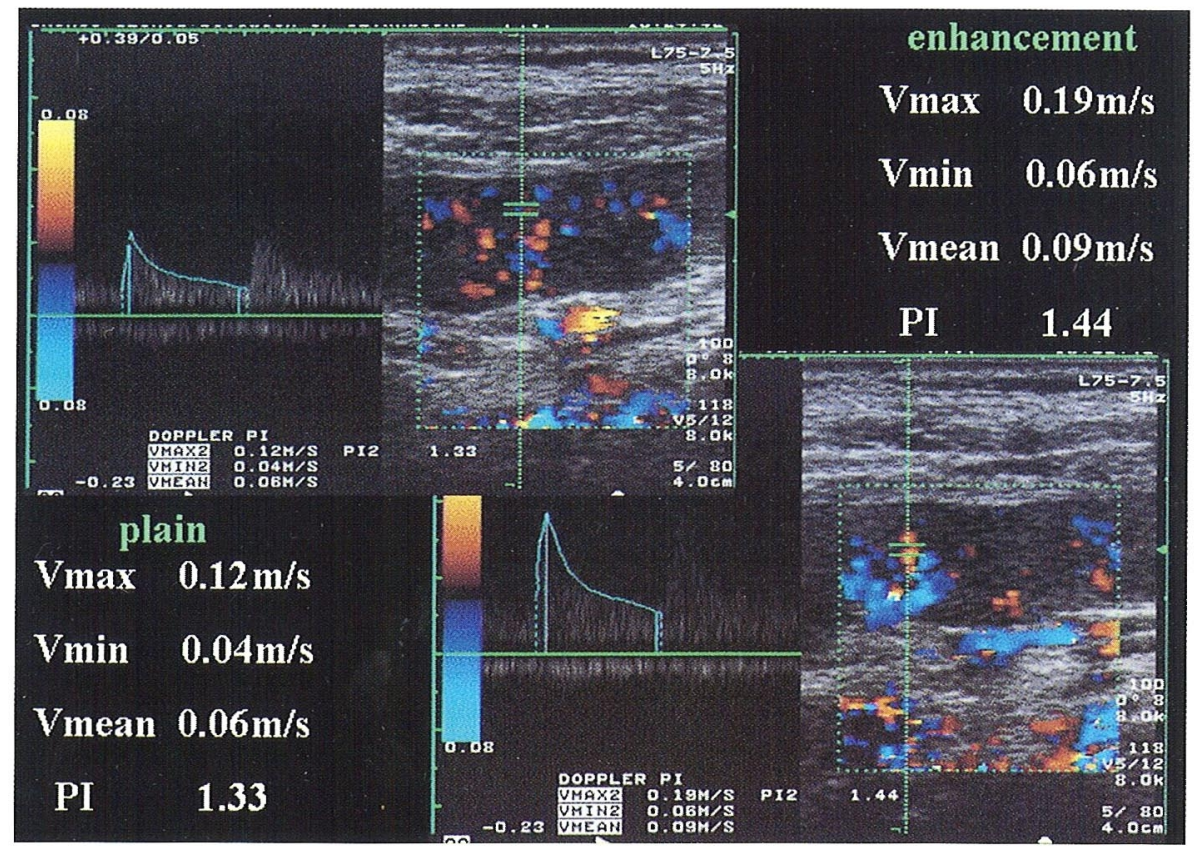


可能であった 1 例について，それぞれの B モード・ ドップラー・エコー画像を供覧する。症例は 37 歳男 性，生体腎移植後 3 カ月で血清クレアチニン值は 1.8 $\mathrm{mg} / \mathrm{dl}$ であった. IL の描出については造影後カラーシ グナルの増強が見られるが, 波型解析のデー夕に誤差 はなかった（図 1)．ILB レベルの血流評価では, 従来 法では同領域のカラーシグナルは弱く, サンプリング は可能であったがかなり困難であった。しかし造影す ることによって ILB 領域のカラーシグナルは増強さ れ, 血管の走行も明瞭に判別可能となり, サンプリン グも容易で, 各パラメーターの解析結果においても, 従来法ではV $\max 0.12 \mathrm{~m} / \mathrm{sec}, V \min 0.04 \mathrm{~m} / \mathrm{sec}$ で あったのに対し,造影法では Vmax $0.19 \mathrm{~m} / \mathrm{sec}, \mathrm{Vmin}$ $0.06 \mathrm{~m} / \mathrm{sec}$ とかなりの差が生じた（図 2).

\section{考 察}

ドップラー法を用いた移植腎血流測定法の歴史は古 く，盲目的に血流シグナルを模索し血流波型を知る初 期の時代から ${ }^{4)}$ ，リニアドップラー複合法の応用で血 流シグナルの発生部位を明らかにして波型解析する方 法を経て ${ }^{566)}$ ，カラードップラー法の導入により臟器の 断層画像上にリアルタイムで血流をカラー表示するこ とで可視化し，血管の部位を確認しつつ血流情報を評 価し得える時代へと変遷した ${ }^{7) ~ 9)}$. この進歩は主に機 器の性能向上に負うところが大きいのが事実だが, 特 に血管の部位を確認しつつ血流測定が可能となった点 は意義深い, その理由は, 腎移植後のモニタリングと して応用するにあたっては, 末梢血流がよりその移植 腎の病態を強く反映することが指摘されており ${ }^{699)}$ ，つ まり直接利尿に関与する末梢循環の評価が重要とされ ているからである，従って本著で試みた超音波造影剤 を用いた皮質微小循環の血流測定は, さらに正確な機 能評価を可能にすることが期待される.

さて本検討で使用した超音波造影剂はガラクトース 微粒子により発生する微小気泡をパルミチン酸によっ て安定化させたものである. 本剤は経静脈的に投与す ることによって血管内の血流シグナルがその微小気泡 により増強され, 最小血管の描出が可能となる ${ }^{233}$. 特 に骨盤内に移植された腎臓は体表からも近く, 呼吸性 移動もないことから, きわめて繊細な位置合わせが要 求される皮質の微小循環の検出が本検討でも全例で可 能であった．以前大熊らは従来法による腎動脈分枝の 血流測定でILBの検出率は 47\%であり，その V max の平均值は $0.17 \mathrm{~m} / \mathrm{sec}$ であったと報告している. 本 検討での従来法による ILB の検出率は $12 \%$ であった
が，これは腎機能不良例を含むことからやや劣ったも のと考えられる。しかし造影剤を用いることにより ILB が全例で描出され，また V max の平均值が $0.15 \mathrm{~m} /$ sec と近似した值を示したことから，信頼性の高い解 析が可能であったと思われる.

また一方では超音波造影剂を用いて血流測定を行っ た場合，同一血管のサンプリングにおいて造影前後で その測定值が異なることが指摘されている ${ }^{11}$. しかし 本検討では造影前後の測定值を比較できるのは従来法 でILB を検出し得たわずか 2 例のみであり，供覧した 実例にも示したように，サンプリングポイントの正確 な位置合わせが測定誤差の重要な要因であったと思わ れる.従ってその造影剂の影響を明確にするためには, 従来法と造影法の両者で明暸に検出しえる血管での測 定値の比較が必要であり，これからの検討課題とした い. またILB レベルの血流評価に如何なる意義がある かについても検討を重ねて明らかにしたいと考えてい る.

\section{文献}

1）池上雅久, 秋山隆弘, 栗田 孝：腎移植における超 音波ドプラ法の有用性. 画像診断，14(3), 309317, 1994.

2）別府慎太郎, 入野忠芳, 中谷 敏, 松田尚雄, 宮武 邦夫：SH/TA-508 臨床第一相試験. 基礎と臨床, 29(12), 3245-3257, 1995.

3）松尾裕英, 高橋則尋, 由良高文, 宮武邦夫, 中谷 敏, 石蔵文信, 安部圭志, 今井 潤, 笹生俊一, 笠 井 豊, 杉崎徹三, 戸塚大輔, 川内章裕, 高元俊彦, 吉田マリ子, 羽田勝征, 伊藤敦彦, 加藤和三, 澤田 準, 森安史典, 吉川純一, 赤土正洋, 小川暢也, 尾 前照雄, 山村秀夫：超音波造影剤 SH/TA-508 の 第一相試験一腎領域における至適用量の検討一. Jpn. J. Med. Ultrasonics, 22 (8), 637-648, 1995.

4) Arima, M., Ishibashi, M., Usami, M., Sagawa, S., Mizutani, S., Sonoda, T., Ichikawa, S., Ihara, H. and Nagano, S. : Analysis of the arterial blood flow patterns of normal and allografted kidneys by the directional ultrasonic Doppler technique.J.Urol., 122, 587-591, 1979.

5）秋山隆弘，西岡 伯，石井徳味，植村匡志，国方聖 司, 神田英憲, 金子茂男, 松浦 健, 栗田 孝: 超 音波 $\mathrm{B}$ モード・パルスドップラー複合装置を用 いた移植腎血流測定法. 日泌尿会誌, 77, 523-529, 1986.

6）西岡 伯, 石井德味, 植村匡志, 国方聖司, 神田英 憲, 金子茂男, 松浦 健, 秋山隆弘, 栗田 孝：超

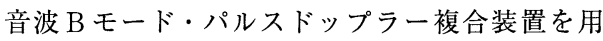
いた移植腎血流測定法. 第 2 報.パターン分類によ 
る検討. 日泌尿会誌，78,907-911, 1987.

7）秋山隆弘, 池上雅久, 今西正昭, 西岡 伯, 石井徳 味, 植村匡志, 国方聖司, 神田英憲, 松浦 健, 栗 田 孝：カラードプラ断層法による移植腎血流測 定法. 日泌尿会誌，79, 1574-1581, 1988.

8）西岡 伯, 池上雅久, 今西正昭, 石井徳味, 植村匡 志, 国方聖司, 神田英憲, 松浦 健, 秋山隆弘, 栗 田 孝：カラードプラ断層法による移植腎血流測 定法. 第 2 報. 移植, 24,351-356, 1989.

9）池上雅久：カラードプラ法による移植腎病態診断 の検討．日泌尿会誌，88,541-549, 1997.
10）大熊 潔，久 直文，布袋伸一，竹田利明，中塚誠 史, 久住浩美, 成松芳明, 平松京一：カラードプラ 法による腎動脈分枝，特に小葉間動脈の血流測定 ・日本医放会誌，53，856-858, 1993.

11）浜田聡明, 別府慎太郎, 石蔵文信, 上田宏昭, 柏木 寧, 矢倉佐知子, 松下恵介, 小林春香: 経静脈性心 筋コントラストエコー法における間歇送信法のた めの同期時相設定に関する検討. J. Med. Ultrasonics, 27, 1037-1041, 2000.

(2000 年 8 月 28 日受付, 2001 年 4 月 9 日受理) 